\title{
EDITORIAL
}

\section{THE DEATH OF ANANDA T. BURBANK}

This is my farewell editorial. I have served on the staff of Horizons now into the seventh year, and that Biblical number suggests to me that it is time to move on, and make way for others more agile of mind and pen.

I had not previously known the exhilaration of working on so new, so pioneering a venture; nor the pleaures of knowing such humane and understanding colleagues. And for all that I am most profoundly appreciative.

I have not been burdened, as are some scribblers, with the need to win over all of my audience. With Confucius, I am inclined to think that it is "not enough" for a man to be liked by everyone. I will admit, however, that it stung a bit to learn that some of my readers found my style sardonic.

I used to think of George Sanders as sardonic. And perhaps Vincent Price (who on second thought looked like an actor trying to look sardonic). For that sardonic look, one's lip has to curl downward. But just on one side, usually the right. When I was in the second grade my mouth curved down in that sinister fashion, and I spoke only out of the corner of my mouth. My generation could all affect a Humphrey Bogart or an Edward G. Robinson manner, almost from the cradle. Not that we were admitted to the movie palaces at such a tender age: we had that look long before ever seeing our celluloid heroes. It was a matter of natural selection.

My own case was quickly resolved by the second grade teacher, a certain Miss Hake (she was no doubt named after the fish). She kept me after school each day and had me recite slowly, five hundred times, the phrase, "How now, brown cow?" Not even George Raft could have stood up against this sort of torture. Within weeks I had lost my calculated irony, and had no choice but to become a cultured person, and then a college professor, and eventually a regular contributor to Horizons.

Satirists are of course commonly mistaken for those who heartlessly deride and ridicule. But the simple truth of the matter is that the satirist is one who finds himself in the position of the small boy in the Hans Christian Andersen tale: as the emperor passes by in regal procession, some unknown compulsion, some unsuspected inner devotion to simple truth, impels him to remark on his monarch's threadbare condition.

In the Confucian academies of yore, I am told, bearded divines debated tirelessly the proposition that man is by nature good, and its corollary, that man is by nature bad. My own thoughts run in a somewhat different direction. Man, as I have known him, is frequently noble, and occasionally foolish. When he is foolish, we owe it to him to point up the 
fact. And the kindest way to do that is not in anger, but with an understanding smile. The satirist hopes that his target will be compelled to smile with him. He is a person of childlike faith. He thinks the emperor already half knows that he is naked.

The hardest task the satirist faces is to manage, in a short space, to be at least half as funny as the truth. Here, for example, is a course description from a catalogue that recently arrived in the mail (I shall withhold the name of the institution-a satirist always disguises or conceals, in order to protect the guilty):

\section{MAPPING OUT YOUR FEET—REFLEXOLOGY}

A microcosm of your entire body is contained within your feet. By manipulating pressure sensitive points on your feet, a massage of any part of your body is possible. This valuable form of toning internal and external organs is safe, easy and enjoyable....A thorough knowledge of your feet can assist in an overall evaluation of health and well being. ... Clean feet and fresh sox are a must.

The satirist's problem is: How can I call my reader's attention to this new fashion, and invoke his innate good sense by giving him a chuckle that will both echo and amplify the guffaw that last line gave me?

Another example: the New York Daily News a few days ago informed its readers that "religious diet books ... are one of the fastest growing segments of the publishing industry," and invited all fat Christians (already a contradiction in terms, it seems to me) to visit the Christian Publications Book Store on Eighth Avenue and 42nd Street (can they have made a mistake in that address?), and sample such titles as Devotions for Dieters, by H. Victor Kane, God Knows I Won't Be Fat Again, by Karen Wise, and More of Jesus, Less of Me, by Joan Cananaugh.

But I am delaying the inevitable. I am setting pen to paper to say that my days as Horizons' well-meaning satirist are over. There is the aforementioned perception that seven years is enough; but there is also the overriding practical consideration that the one man I had relied upon to keep me in touch with the demi-monde of American popular spirituality is no longer with us. It is with unspeakable sadness that I must inform my readers of the premature passing of Ananda T. Burbank. Reports reached me just last week that Professor Burbank, having achieved some small fame through the work of his Institute for Holistic Pedaphysics in Boston, and the publication of his book The Unicycle Way to Pedal Awareness, was doing a lecture-demonstration of his discoveries in reflexology before the Augustinian community in Smoke Hole, West Virginia, when he developed a sudden fit of ticklishness while demonstrating soul therapy, and was unable to stop laughing. He was 
taken to the emergency ward of the Dr. Steven B. Gurdak General Hospital in Buckhannon, but according to the morning edition of the Buckhannon Bugle, attempts at sedation were unsuccessful, and he died laughing.

If I may venture to say so, whatever finality death may appear to have, the spirit of this man will live on long after these words shall have faded into illegibility.

His epitaph might be these words of the Master K'ung: "A neighborhood's beauty is its humanity. He who has not lived among real people, how can he know?"

Come to think of it, that pretty well sums up how I feel about my colleagues on the staff of Horizons, too.

—ALBERT WILLIAM SADLER 


\section{Significant Reading on Religions, Nature, and the Resurrection}

\section{TRUTH IS TWO-EYED}

by JOHN A.T. ROBINSON. How Eastern religions and Christianity approach the same religious truth in different ways. Paper $\$ 6.95$

\section{THEOLOGY OF NATURE}

by GEORGE S. HENDRY. A perceptive, revealing inquiry into the world of nature, the doctrine of creation, and the work of the Holy Spirit. Soft Cover $\$ 10.95 \mathrm{t}$

\section{THE RESURRECTION OF JESUS CHRIST IN NEW TESTAMENT THEOLOGY}

by JOHN FREDERICK JANSEN. A fresh, substantial contribution on the meaning of Easter as a unifying focus in New Testament theology. Soft Cover \$8.95t

$\mathrm{t}$ - tentative price

Now at your bookstore, or order direct from the publisher. 